\title{
Effects of Trophectoderm Dissection on Development of Inner Cell Mass of Fresh and Frozen-Thawed Bovine Blastocysts Derived from In-Vitro Fertilization
}

\author{
Xihe LI, Setsuo IWASAKI, and Tatsuo NAKAHARA \\ NODAl Research Institute, Tokyo University of Agriculture, \\ Sakuragaoka 1-1-1, Setagaya-ku, Tokyo 156, Japan
}

\begin{abstract}
A part of trophectoderm cells was dissected microsurgically from bovine blastocysts fertilized in vitro for sex determination by chromosome analysis and its effects on the proliferation of inner cell mass (ICM) of fresh and frozen-thawed embryos were investigated by a differential fluorochrome staining technique. In total, 188 blastocysts were dissected and $85.5 \%$ (65/76) of embryos cultured in vitro for $24 \mathrm{~h}$ was repaired. Mitotic index $(14.9 \%)$ and sexing rate $(57.1 \%)$ of unrepaired embryos after dissection were lower than those $(19.9 \%$ and $66.0 \%$ ) of repaired embryos but not significant. Further culture resulted in significant decreases in the repair rates $(48 \mathrm{~h}: 37.5 \%, 72 \mathrm{~h}$ : $32.5 \%, 96 \mathrm{~h}: 28.6 \%$ ) but not in embryos co-cultured with cumulus cells monolayer (96 h: $81.8 \%$ ). The proliferation of ICM cells was inhibited up to $72 \mathrm{~h}$ after in-vitro culture and it was promoted thereafter. Survival rates of frozen-thawed embryos, which was repaired after the dissection decreased significantly from $12 \mathrm{~h}$ after the initiation of in-vitro co-culture. Total and live ICM cell numbers increased slightly with in-vitro culture but not significant. These results show that the proliferative ability of ICM cells becomes temporarily arrested by the dissection of trophectoderm cells but is resumed by the subsequent in-vitro culture. In addition, it was suggested that the applicable time of transplantation of dissected and frozen-thawed embryo is within $2 \mathrm{~h}$ after thawing.
\end{abstract}

Key words: Bovine blastocysts, Dissection, Inner cell mass, Freezing.

(J. Reprod. Dev. 39: 281-286, 1993)

$\mathbf{T}$ here are many reports on sexing of bovine embryos by chromosome analysis [1-3] or detection of Y-specific DNA sequence [4-6] using microsurgically dissected or biopsied cells. In these studies, size of the dissected portion varied from half of the embryos [1-3] to a small portion $(>15$ cells) [6] or only a few cells [7]. However, little is known concerning the effects of dissection or bisection of embryos and freezing of these embryos on the subsequent development of embryos, especially on inner cell mass (ICM) proliferative ability.

In the present study, mitotic index and sexing rates by chromosome analysis in repaired embryos after the dissection of trophectoderm cells was compared to those of unrepaired embryos. The

Accepted for Publication: June 19, 1993

Correspondence: S. Iwasaki relationship between culture time after the dissection and the in-vitro proliferation of ICM cells was also studied by a differential fluorochrome staining technique [8, 9]. Finally, the dissected and repaired embryos were frozen by a three-step method [10], and survival rates and the number of live ICM cells of thawed embryos were investigated.

\section{Materials and Methods}

Preparation of bovine blastocysts

Follicular oocytes obtained from ovaries of Holstein cows were cultured in vitro as described previously [11]. Briefly, cumulus-oocytes complexes were cultured in $25 \mathrm{mM}$ HEPES-buffered 
TCM 199 supplemented with $5 \%$ fetal bovine serum (FBS) and antibiotics for $20 \mathrm{~h}$ at $38.5 \mathrm{C}$ in $3 \% \mathrm{CO}_{2}-97 \%$ air. In-vitro fertilization of matured oocytes was carried out by the caffeine-heparin method as described by Niwa et al. [12] with minor modifications. Frozen spermatozoa from Japanese Black bulls were thawed and washed twice with Brackett and Oliphant's medium [13] including 10 $\mathrm{mM}$ caffeine sodium benzoate (Sigma Chemical Co., MO, USA) and the final sperm concentration was adjusted to $2 \times 10^{7} / \mathrm{ml}$. Fifty microliter of the final sperm suspension was added to $50 \mu \mathrm{l}$ of the medium containing $20 \mu \mathrm{g} / \mathrm{ml}$ of heparin sodium (Novo Industry, Denmark) and $5 \mathrm{mg} / \mathrm{ml}$ of bovine serum albumin (BSA, Fraction V, Wako Jyunyaku Co., Ltd., Tokyo) that included cumulus-oocytes complexes. The final concentrations of spermatozoa, caffeine, heparin and bovine serum albumin (BSA) were $1 \times 10^{7} / \mathrm{ml}, 5 \mathrm{mM}, 10 \mu \mathrm{g} / \mathrm{ml}$ and 2.5 $\mathrm{mg} / \mathrm{ml}$, respectively. Cumulus cell monolayer was prepared by culturing cumulus cells alone under similar conditions. The oocytes were transferred to the same medium as used for oocyte maturation $5 \mathrm{~h}$ after insemination and co-cultured with a monolayer of cumulus cells [14] for obtaining expanded blastocysts.

\section{Dissection of trophectoderm cells}

A total of 188 expanded blastocysts obtained at 7 to 8 days after insemination were used for the dissection of trophectoderm cells. The blastocysts were treated with $0.25 \%$ pronase (Actinase E, Kaken Seiyaku, Tokyo) in phosphate buffered saline (PBS) for 2 to $3 \mathrm{~min}$ to weaken the zona pellucida. Then, one-third of the trophectoderm at the opposite side of the inner cell mass (ICM) was dissected by a single vertical slicing with a microsurgical blade (Shin-etsu Kagaku Co., Ltd, Tokyo) attached to a micromanipulator (Narishige Sci. Inst. Lab., Tokyo). The dissected trophectoderm cells were cultured further in conditioned medium which was prepared by the culture of cumulus cells in $25 \mathrm{mM}$ HEPES-buffered TCM 199 supplemented with 5\% FBS and antibiotics for $12 \mathrm{~h}$.

\section{Chromosome preparation}

The chromosome preparation of dissected and cultured trophectoderm cells was made by the method described previously [11] with minor modifications. Briefly, the trophectoderm cells cultured in TCM 199 medium containing 0.4 $\mu \mathrm{g} / \mathrm{ml}$ of vinblastine (Sigma Chemical Co.) for $4 \mathrm{~h}$ were placed in $0.9 \%$ sodium citrate as a hypotonic solution for $8 \mathrm{~min}$ at room temperature. They were then fixed in an acetic acid-methanol-sodium citrate solution $(5: 15: 8)$ for $15 \mathrm{~min}$, followed by an acetic acid-methanol solution (1:3) for $20 \mathrm{~min}$. The chromosome preparations were stained with $4 \%$ Giemsa (Merck Japan, Tokyo) at $\mathrm{pH} 6.8$ for 3.5 min, air-dried and mounted in Eukitt (O. Kinder, Germany). The sex of the cells was determined by 2 cytogenetists independently and only coincident data were used.

\section{Culture of embryos after the dissection}

The operated embryos were further cultured in HEPES-buffered TCM 199 supplemented with $5 \%$ FBS without co-culture for 24, 48, 72 and $96 \mathrm{~h}$. A portion of the operated embryos was cocultured with cumulus cells monolayer for $96 \mathrm{~h}$. The blastocysts which formed a blastocoele were defined as repaired embryos but the others which formed a contracted or shrunken blastocoele were defined as unrepaired embryos.

\section{Differential ICM/trophectoderm cell counts of repaired blastocysts}

The numbers of ICM and trophectoderm cells were counted by the method described previously $[8,9]$ with minor modifications. The repaired blastocysts were incubated with $10 \%$ rabbit antibovine spleen cell antiserum for $30 \mathrm{~min}$ at $38.5 \mathrm{C}$ in $3 \% \mathrm{CO}_{2}-97 \%$ air. Then, the blastocysts were washed 5 times in PBS containing $0.3 \%$ BSA and then incubated with $10 \%$ complement solution (guinea-pig serum) containing propidium iodide (PI, Sigma Chemical Co.) and bisbenzimide (Hoechst 33342) each at a final concentration of 10 $\mu \mathrm{g} / \mathrm{ml}$ for $30 \mathrm{~min}$ at $38.5 \mathrm{C}$. Finally, the blastocysts were washed in PBS with $0.3 \%$ BSA and transferred on to a glass slide. The embryo preparation was examined using a Nikon fluorescence microscope with an excitation filter $(365 \mathrm{~nm})$ in combination with a barrier filter $(420 \mathrm{~nm})$. The numbers of blue-fluorescing live ICM cells and pink-fluorescing trophectoderm cells were separately counted and embryos with no blue-stained ICM cells were omitted from the data.

\section{Freezing and thawing of dissected blastocysts}

Repaired blastocysts cultured for $24 \mathrm{~h}$ after the 
operation were frozen and thawed by a three-step method of Niemann [10] with minor modifications. Briefly, embryos were placed in order into PBS with 20\% calf serum and 3, 6 and 10\% glycerol after keeping each for $10 \mathrm{~min}$ at room temperature. Then the embryos were loaded into the middle part of $0.25 \mathrm{ml}$-straws separated by two air bubbles and the straws were cooled from $20 \mathrm{C}$ to $-7 \mathrm{C}$ at a rate of $1 \mathrm{C} / \mathrm{min}$. After manual seeding, straws were kept at $-7 \mathrm{C}$ for further 10 min and were then cooled to $-28 \mathrm{C}$ at a rate of $0.3 \mathrm{C} / \mathrm{min}$ and to $-35 \mathrm{C}$ at $0.1 \mathrm{C} / \mathrm{min}$. Finally they were plunged in liquid nitrogen for 7 days to one month. For thawing, straws were introduced into warm water at $37 \mathrm{C}$ and the contents were transferred to PBS containing $0.7 \mathrm{M}$ sucrose and $0.7 \mathrm{M}$ glycerol for 10 min followed by transfer to PBS with $0.7 \mathrm{M}$ sucrose for $10 \mathrm{~min}$. Thawed embryos were co-cultured with monolayer of cumulus cells for 2, 6, 12 or $24 \mathrm{~h}$ in HEPES-buffered TCM 199 supplemented with 5\% FBS and antibiotics. The blastocysts, which formed a blastocoele after coculture, were defined as survived embryos. Differential ICM/trophectoderm cell counts were performed in survived embryos.

In a preliminary investigation, pink-stained dead cells were observed in ICM. This finding led us to investigate the proportion of dead ICM cells in frozen-thawed embryos. At first, ICM was isolated from trophectoderm cells using a glass needle with a thin tip under the microscope. Isolated ICM was mounted on a glass slide, then the total number of ICM cells was counted after Giemsa staining. The number of dead ICM cells (pink-stained) was calculated by subtracting the number of live ICM cells from the total ICM cell number.

Data were compared using the Chi-square test and Student's $t$-test.

\section{Results}

Sex determination of bovine embryos by chromosome analysis

As shown in Table 1, of 76 dissected embryos, $65(85.5 \%)$ were repaired after culture for $24 \mathrm{~h}$. The numbers of dissected trophectoderm cells and of cells with metaphase plates in repaired and unrepaired blastocysts were 14.6 and 2.8 , and 13.8 and 2.0, respectively. Sexing rates of the repaired and unrepaired blastocysts were $66.0 \%$ and $57.1 \%$, respectively. The mitotic index $(14.9 \%)$ and sexing rate $(57.1 \%)$ of dissected trophectoderm cells from unrepaired blastocysts were slightly lower than those $(19.9 \%$ and $66.0 \%)$ from repaired ones.

\section{Differential ICM/trophectoderm cell counts of repaired blastocysts}

The morphology of dissected embryos, especially in trophectoderm cells, changed rapidly from 72 $\mathrm{h}$ to $96 \mathrm{~h}$ after in-vitro culture (Fig. 1). Outgrowth of trophectoderm cells on the surface of culture dish started at $48 \mathrm{~h}$ after culture and made it difficult to count the cell number.

As shown in Table 2, the rate of repaired embryos significantly $(\mathrm{P}<0.05)$ decreased from 24 $\mathrm{h}(85.5 \%)$ to $48 \mathrm{~h}(37.5 \%)$ after culture but such a

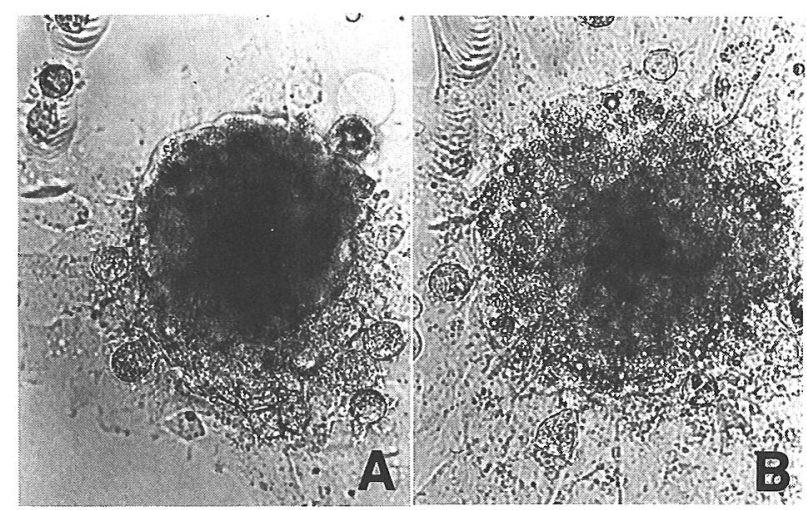

Fig. 1. Repaired bovine embryo by culture for $72(\mathrm{~A})$ and $96 \mathrm{~h}$ (B) after trophectoderm cell dissection.

Table 1. Mitotic index and sexing rate of repaired and unrepaired bovine blastocysts cultured without co-culture for $24 \mathrm{~h}$ after dissection

\begin{tabular}{lccccc}
\hline & $\begin{array}{c}\text { No. of } \\
\text { embryos }\end{array}$ & $\begin{array}{c}\text { No. of } \\
\text { dissected } \\
\text { cells (A) }\end{array}$ & $\begin{array}{c}\text { No. of cells } \\
\text { with metaphase } \\
\text { plates (B) }\end{array}$ & $\begin{array}{c}\text { Mitotic } \\
\text { index } \\
\text { (B/A, \%) }\end{array}$ & $\begin{array}{c}\text { Sexing rate } \\
\% \text { (sexed/ } \\
\text { analysed) }\end{array}$ \\
\hline Repaired & 65 & $14.6 \pm 1.0^{*}$ & $2.8 \pm 0.3^{*}$ & $19.9 \pm 1.6^{*}$ & $66.0(33 / 50)$ \\
Unrepaired & 11 & $13.8 \pm 2.2$ & $2.0 \pm 0.3$ & $14.9 \pm 3.0$ & $57.1(4 / 7)$ \\
\hline
\end{tabular}

*Mean \pm SE 
Table 2. Inner cell mass (ICM) cell number of repaired embryos in culture for 24 to $96 \mathrm{~h}$ after dissection

\begin{tabular}{|c|c|c|c|c|c|c|}
\hline \multirow{2}{*}{ Treatment } & \multirow{2}{*}{$\begin{array}{l}\text { Culture } \\
\text { time(h) }\end{array}$} & \multirow{2}{*}{$\begin{array}{l}\text { No. of } \\
\text { dissected } \\
\text { embryos }\end{array}$} & \multirow{2}{*}{$\begin{array}{c}\text { No. of } \\
\text { repaired } \\
\text { embryos }(\%)\end{array}$} & \multicolumn{3}{|c|}{ No. of cells } \\
\hline & & & & Total & $\operatorname{ICM}(\%)$ & Trophectoderm \\
\hline \multirow[t]{5}{*}{ Dissected } & 24 & 76 & $65(85.5)^{\mathrm{a}}$ & $47.1 \pm 1.3$ & $\begin{array}{c}13.4 \pm 0.5^{\mathrm{a}} \\
(29.2 \pm 1.1)\end{array}$ & $33.8 \pm 1.2$ \\
\hline & 48 & 40 & $15(37.5)^{\mathrm{b}}$ & ND* & $15.9 \pm 1.1^{\mathrm{a}}$ & ND \\
\hline & 72 & 40 & $13(32.5)^{b}$ & ND & $29.7 \pm 3.1^{\mathrm{b}}$ & ND \\
\hline & 96 & 21 & $6(28.6)^{b}$ & ND & $37.2 \pm 4.6^{\mathrm{b}}$ & ND \\
\hline & $96^{* *}$ & 11 & $9(81.8)^{a}$ & ND & $41.4 \pm 3.9^{\mathrm{b}}$ & ND \\
\hline Intact & 24 & - & 29 & $64.9 \pm 1.1$ & $16.8 \pm 0.5^{\mathrm{a}}$ & $49.3 \pm 1.2$ \\
\hline
\end{tabular}

* Not determined.

**Co-culture with cumulus cell monolayer.

${ }^{\mathrm{a}, \mathrm{b}}$ Values with different superscripts were significantly different for rate of repaired embryos $(\mathrm{P}<0.05)$ and for ICM cell numbers $(\mathrm{P}<0.01)$.

Table 3. Survival and number of inner cell mass (ICM) of presexed bovine embryos in culture for 2-24 $\mathrm{h}$ after freezing and thawing

\begin{tabular}{|c|c|c|c|c|c|c|}
\hline & \multirow{2}{*}{$\begin{array}{l}\text { Culture } \\
\text { time(h) }\end{array}$} & \multicolumn{2}{|c|}{ No. of embryos } & \multicolumn{3}{|c|}{ No. of ICM $($ Mean \pm SE) } \\
\hline & & Examined & Survived(\%) & Total & Live & Dead $(\%)$ \\
\hline \multirow{4}{*}{$\begin{array}{l}\text { Frozen- } \\
\text { thawed }\end{array}$} & 2 & 27 & $22(81.7)^{\mathrm{a}}$ & $18 \pm 1$ & $15 \pm 1$ & $3 \pm 0(16.2 \pm 1.9)$ \\
\hline & 6 & 19 & $14(72.2)^{\mathrm{ab}}$ & $19 \pm 2$ & $17 \pm 1$ & $2 \pm 0(10.2 \pm 2.2)$ \\
\hline & 12 & 18 & $12(66.7)^{\mathrm{b}}$ & $21 \pm 2$ & $18 \pm 1$ & $3 \pm 1(14.9 \pm 2.1)$ \\
\hline & 24 & 29 & $18(62.4)^{b}$ & $22 \pm 3$ & $18 \pm 2$ & $4 \pm 1(18.2 \pm 1.5)$ \\
\hline Fresh & 24 & 26 & - & $23 \pm 2$ & $19 \pm 1$ & $3 \pm 1(14.6 \pm 1.7)$ \\
\hline
\end{tabular}

${ }^{a, b}$ Values with different superscripts were significantly different $(\mathrm{P}<0.05)$.

decrease was not observed in embryos co-cultured with cumulus cells for $96 \mathrm{~h}$. An increase in the number of ICM cells in dissected and repaired embryos was not observed up to $48 \mathrm{~h}$ after culture and the proliferation of ICM cells was temporarily inhibited by trophectoderm dissection treatment. Thereafter, the ICM cell number increased significantly $(\mathrm{P}<0.01)$ from $15.9(48 \mathrm{~h})$ to $29.7(72 \mathrm{~h})$ and $37.2(96 \mathrm{~h})$, although there was no significant difference in the ICM cell number at $96 \mathrm{~h}$ after culture between 2 different culture systems.

\section{Viability of dissected blastocysts after freezing and thawing}

As shown in Table 3, survival rate was $81.7 \%$ at $2 \mathrm{~h}$ after thawing but significantly $(\mathrm{P}<0.05)$ decreased to $66.7 \%$ and $62.4 \%$ at 12 and $24 \mathrm{~h}$ after culture, respectively. Total ICM cell number was slightly increased from 18 at $2 \mathrm{~h}$ to 22 at $24 \mathrm{~h}$ with progressed period of culture with no significance. There was no significant difference in the propor- tions (10.2 to $18.2 \%)$ of dead ICM cells among frozen-thawed embryos cultured for 2 to $24 \mathrm{~h}$. Intact embryos also included some dead ICM cells and its proportion was similar to that from frozen-thawed embryos.

\section{Discussion}

Biopsy or dissecton of trophectoderm cells is an essential process to determine the sex of embryos by chromosomal analysis [1-3], polymerase chain reaction $[5,6]$ or fluorescent in situ hybridization [4] using the Y-chromosome specific DNA fragment. However, to maximize the viability of treated embryos, damage on embryos during biopsy or dissection should be minimized.

Although there was no significant difference, blastocoele formation in repaired embryos cultured for $24 \mathrm{~h}$ after dissection showed a higher mitotic index and sexing rates than those in 
unrepaired embryos. This could possibly attribute to the lower viability of unrepaired embryos. The sexing rate in the present study was $66 \%$ using one-third (average 14 cells) of the trophectoderm cells. Picard et al. [3] found that approximately $60 \%$ of bovine demi-embryos fertilized in vitro could be sexed at Day 6 to 7 . Accordingly, there was no problem in the viability of dissected embryos to investigate the total and ICM cell numbers.

In general, co-culture with oviduct cells is more effective in ruminant embryo development than that with uterine, kidney or fibroblast cells [15]. Eyestone and First [16] showed that co-culture with oviductal tissue or culture in conditioned medium from oviduct tissue enhanced development of early bovine embryos to the blastocyst stage. In the present study, the dissected embryos were cultured in vitro without co-culture to avoid any kind of interference, so that the precise count of the number of trophectoderm cells by the differential fluorochrome staining technique can be carried out. However, this culture system significantly reduced the proportion of repaired embryos reaching the blastocyst stage when the period of culture was prolonged (Table 2). In order to confirm the effect of culture system on the repair rates, the operated embryos were co-cultured with cumulus cells. At $96 \mathrm{~h}$ after culture, the rate of repaired embryos when they were cultured with $(81.8 \%)$ was higher than without $(28.6 \%)$ cumulus cells. Accordingly, importance of co-culture with cumulus cells during culture of embryos derived from in-vitro fertilization was confirmed.

In the present study, outgrowth of a part of trophectoderm cells was observed on the surface of culture dish at 48 to $96 \mathrm{~h}$ after culture of dissected embryos (Fig. 1) and determination of trophectoderm cell numbers during this period was difficult. However, it was possible to count ICM cell numbers by the differential fluorochrome staining technique because tight junctions of trophectoderm cells could be repaired during culture. The culture of dissected embryos resulted in the recovery in the proliferation of
ICM cells from $72 \mathrm{~h}$. On the other hand, there was no significant difference in ICM cell number between repaired embryos cultured with and without cumulus cells for $96 \mathrm{~h}$. These results show that proliferation of ICM cells is arrested temporarily by dissection but can resume with increasing culture time regardless of the cumulus cell coculture.

Recently, establishment of embryonic stem cell lines from domestic animals has been attempted [17]. Evans et al. [17] observed that the proliferation rate of stem-like cells from porcine embryos is slower than those derived from murine embryos. They suggested that the period of ICM quiescence in ungulates up to the time of gastulation is different from that of mice. Our data show that at least $72 \mathrm{~h}$ is needed to resume ICM cell proliferation after dissection. This may offer a clue to resolving this comparative species difference in the developmental schedule.

In general, it was known that the survival and pregnancy rates of dissected and frozen-thawed embryos are lower comparing with the ordinary frozen-thawed or the bisected fresh embryos [18-20]. These investigations indicated that approximately $30-50 \%$ of frozen-thawed bovine demi-embryos were considered to be viable morphologically and only $20-30 \%$ of them could develop to advanced stage during subsequent culture [19-21]. In our data, higher survival rates $(81.5-62.4 \%)$ of biopsied bovine blastocysts were obtained after freezing and thawing and it displayed higher growth rate in ICM with in-vitro coculture up to $24 \mathrm{~h}$ after thawing. This shows the importance of cumulus cell co-culture for survival and development of frozen-thawed bovine embryos.

\section{Acknowledgment}

The authors wish to thank Mr. Hitoshi Ushijima, Chiba Prefectural Livestock Center, for his guidance of microsurgical dissection technique of bovine blastocysts. 


\section{References}

1. Hare WCD, Mitchell D, Betteridge KJ, Eaglesome MD, Randall GCB. Sexing two-week old embryos by chromosomal analysis prior to surgical transfer preliminary methods and results. Theriogenology 1976; 5: 243-253.

2. Singh EL, Hare WCD. The feasibility of sexing bovine morula stage embryos prior to embryo transfer. Theriogenology 1980; 14: 421-427.

3. Picard L, King WA, Betterige KJ. Production of sexed calves from frozen-thawed embryos. Vet Rec 1985; 117: 603-608.

4. Leonard M, Kirszenbaum M, Cotinot $\mathbf{C}$, Chesne $P$, Heyman Y, Stinnakre MG, Bishop C, Delouis C, Vaiman M, Fellous M. Sexing bovine embryos using Y chromosome specific DNA probe. Theriogenology 1987; 27: 248 (Abstract).

5. Herr CM, Holt NA, Matthaei KI, Reed KC. Sex of progeny from bovine embryos sexed with a rapid Y-chromosoma-detection assay. Theriogenology 1990; 33: 247 (Abstract).

6. Bondioli KR, Ellis SB, Pryor JH, Williams MW, Harpold MM. The use of male-specific chromosomal DNA fragments to determine the sex of bovine preimplantation embryos. Theriogenology 1989; 31: 95-104.

7. Herr CM, Reed KC. Micromanipulation of bovine embryos for sex determination. Theriogenology 1991; 35: 45-54.

8. Iwasaki S, Yoshida Y, Watanabe S, Nakahara T. Differential nuclear staining and cell count of trophectoderm and inner cell mass of bovine blastocysts fertilized in vitro by double fluorochrome dye technique. Jpn J Anim Reprod 1990; 36: 60-65 (In Japanese).

9. Iwasaki S, Yoshiba N, Ushijima H, Watanabe $\mathbf{S}$, Nakahara T. Morphology and proportion of inner cell mass of bovine blastocysts fertilized in vitro and in vivo. $J$ Reprod Fert 1990; 90: 279-284.

10. Niemann H. Cryopreservation of ova and embryos from livestock current status and research needs. Theriogenology 1991; 35: 109-124.

11. Iwasaki S, Hamano S, Kuwayama M, Yamashita
M, Ushijima H, Nagaoka S, Nakahara T. Developmental changes in the incidence of chromosome anomalies of bovine embryos fertilized in vitro. $J$ Exp Zool 1992; 261: 79-85.

12. Niwa K, Ohgada O. Synergistic effect of caffeine and heparin on in-vitro fertilization of cattle oocytes matured in culture. Theriogenology 1988; 30: 733-741.

13. Brackett BG, Oliphant G. Capacitation of rabbit spermatozoa in vitro. Biol Reprod 1975; 12: 260-274.

14. Kajihara Y, Goto K, Kosaka S, Nakanishi Y, Ogawa K. In vitro fertilization of bovine follicular oocytes and their development up to hatched blastocysts in vitro. Jpn J Anim Reprod 1987; 33: 173-180 (In Japanese).

15. Caird E, Rexroad S. Co-culture of domestic animal embryos. Theriogenology 1989; 31: 105-114.

16. Eyestone WH, First NL. Co-culture of early cattle embryos to the blastocysts stage with oviducal tissue or in conditioned medium. J Reprod Fert 1989; 85: 715-720.

17. Evans MJ, Notarianni E, Laurie S, Moor RM. Derivation and preliminary characterization of pluripotent cell lines from porcine and bovine blastocysts. Theriogenology 1990; 33: 125-128.

18. Niemann H, Brem G, Sacher B, Smidt D, Krausslich H. An approach to successful freezing of demi-embryos. Theriogenology 1986; 25: 519-524.

19. Voelkel SA, Hu XY. Use of ethylene glycol as a cryoprotectant for bovine embryos allowing direct transfer of frozen-thawed embryos to recipient females. Theriogenology 1992; 37: 687-697.

20. Nagashima H, Kato Y, Yamakawa H, Yokoyama K, Kato M, Sawasaki T, Kobayashi K, Ogawa S. Studies on freezing preservation and sexing of bisected embryos in pigs, cows, goats and rabbits. Jpn J Anim Reprod 1990; 35: 69-75 (In Japanese).

21. Rorie RW, Pendleton RJ, Youngs CR, Godke RA. Viability of demi-embryos produced before VS. after deep freezing. Theriogenology 1986; 25: 192 (Abstract). 